\title{
1
}

\section{Linking markets for Chinese growth}

\author{
Ross Garnaut
}

The world is in its fifth year of extraordinarily strong economic growth and Chinese economic growth is at its centre. Strong growth with low to moderate inflation and historically low real interest rates is the global norm in 2007.

The linking of markets has been a key to accelerated and sustained growth in China and its transmission to the global economy. The beginnings of the use of markets at the dawn of Chinese reform 29 years ago triggered what turned out to be a long-term lift in the rate of economic growth. The span of time joining the present to the decisive political events that set reform and opening to the outside world in motion in December 1978 is now as long as the whole life of Maoist central planning. Since the late 1970s, Chinese domestic markets for goods, services, capital and labour have been linked more and more closely, under the pressures of market opportunity that have been created by expanded reform. Chinese economic interaction with the global community proceeded alongside the expansion of domestic markets, helping to drive the domestic processes. Chinese entry into the World Trade Organization (WTO) in November 2001 helped-most importantly through the changes in domestic policies and attitudes that accompanied it-to maintain momentum in international integration.

Chinese international trade and capital flows have grown more rapidly than domestic output or expenditure throughout the reform era. This has had large effects on economic development far beyond China's borders. Driven by relentless expansion of Chinese demand, global commodity prices-the export mainstays of the poorer developing economies-have reached and remained at levels in real terms that are higher than they have ever been for comparably long periods, 
without upsetting the strong trajectory of non-inflationary growth in China or the rest of the world (Garnaut and Song 2006). The flow of capital from China has helped to hold real interest rates at historically low levels all over the world, despite unprecedentedly high budget deficits in the United States. This has been important in reconciling high levels of investment and growth with moderate inflation through a period of exceptionally strong global expansion.

Within China-supported by the beneficent international environment, and driving it-growth in the past year has lifted a notch, and with it investment, real incomes of most workers and most people, and domestic asset values.

The widening reach of markets and the associated rapid growth has forced structural change in established institutions and patterns of production, resource allocation and income distribution throughout the Chinese economy. Inevitably, this has been associated with political tensions; however, the sustained strong growth so far has been less and less problematic as the years have passed.

Wise observers continue to note that China will face challenges in adapting its political superstructure to the changes in society that accompany sustained rapid growth. The wisest note that for the time being the growth in incomes and wealth is a salve for many wounds, and that eventual change might not necessarily take forms that are familiar in detail to citizens of industrialised countries.

The most challenging questions about the sustainability of growth today come from China's relations with the international economy. The combination of the emergence of China as a large economy on a world scale and deepening market linkages to the global economy means that change in China is felt as pressure on resources and pressure for structural change in the rest of the world. This has made the institutions and policies through which China interacts with the global economy a matter of intense interest for people everywhere.

The sharpest point of contention in China's external economic relations at present is the foreign exchange value of the renminbi. ${ }^{1}$ Exchange rate appreciation accelerated in early 2007 against the US dollar, but remained gradual to the point of exasperation to those who looked for this to be the mechanism for correction of payments surpluses. Exports continue to grow strongly - and imports moderately - as productivity growth outweighs the effects on international competitiveness of rising labour costs and currency appreciation. This raised tensions with the United States. Less obvious to those in the international community who regret the scale of Chinese current surpluses are the massive purchases of Western financial instruments, especially US official securities, which underpin contemporary global stability and growth by keeping real interest rates well below what they would otherwise be. Woo and Xiao (Chapter 4) caution about the consequences of US policymakers getting what they wish for in the way of large reductions in the Chinese trade and current account surpluses. Any fracture in China's trade or payments relations with 
the international system that emerged from industrialised countries' political responses to Chinese surpluses would threaten prosperity through this financial as well as real economy mechanisms.

A rapidly emerging point of contention is China's contribution to the global warming problem. China is still a relatively small contributor to the accumulation of greenhouse gases in the atmosphere, which began with the acceleration of human use of fossil fuels accompanying the emergence of modern industrial activity 200 years ago. The problem has crept up on the world-without market processes automatically generating a corrective response-because the costs of greenhouse gas emissions are external to the calculations of any firm or household undertaking activities that release them into the atmosphere. Stern (2007) has commented that this represents the most important market failure in human history. The international nature of the greenhouse gas externalities makes this a particularly daunting challenge.

China is not a major part of the reason why the world faces large problems of anthropogenic warming at this time. The arrival of sustained rapid growth in China, however, fuelled to an unusual extent by coal-the most emissionsintensive of major energy sources-is accelerating the world's movement towards critical points. In 2006, China overtook the United States as the largest current emitter of greenhouse gases (Song and Sheng, Chapter 12). This coincided with increasing awareness throughout the international communityincluding in China and the United States, following Europe and Japan some time ago - that anthropogenic global warming is a problem of large dimension, requiring a strong response from the international community.

The contribution of Chinese growth to global warming raises the most critical and difficult questions about the sustainability of the contemporary pattern of Chinese economic growth. This potential threat to future global prosperity is in some ways the other side of the coin to the exceptional prosperity that Chinese growth has conferred on the world, and especially to resource-rich countries such as Australia and some of its developing-country neighbours. The answers lie in creating new markets-inside China and internationally - to enhance the social and economic efficiency of all of the other markets whose deepening and improvement have generated the current Chinese and global prosperity.

The chapters in this book discuss recent developments in international markets in China, in ways that illuminate the main contemporary challenges to Chinese growth: the linkages that shape the terms of capital flows in China and with the international economy; the linkages that frame the national labour market during the historic transition, which was described last year and since as the 'turning point in China's economic development' (Garnaut and Huang 2006); the quality of markets for goods and services within China and their connections with the rest of the world; and the global market failures associated 
with the global warming problem. The Chinese exchange rate issue is important in discussion of capital flows and trade, and is covered in greatest detail when it first arises in relation to capital movements.

\section{Linking capital markets and the role of the exchange rate}

The deepening integration of domestic capital markets and increasing international capital flows are discussed in almost half of the chapters in this volume. Garnaut and Huang (Chapter 2) show that the rapid expansion of Chinese foreign trade continued in 2006 and early 2007. The increase in the trade surplus has accelerated, as have the current account surplus and growth in foreign reserves. The accumulated depreciation of the renminbi exchange rate since the loosening of the tie to the US dollar in 2005 has been too small to affect significantly either real economic transactions or the politics of external economic relations.

Woo and Xiao (Chapter 4) delve further into these issues, and analyse the debate in the United States on the deficit with China. It makes sense for China to contribute to reduction of the payments surplus, but effective adjustment would require use of a wider range of Chinese policy instruments than those that feature in the American discussion, and also policy adjustment in the United States. There are risks that misjudgement on two sides of the Pacific could be damaging to both.

Ma and McCauley (Chapter 14) note the extraordinary intensification of links with global capital markets reflected in growth of gross capital flows to the extent that they now exceed annual gross domestic product (GDP). This has widened opportunities for avoiding official controls. Nevertheless, interest rates continue to move with global rates only partially (adjusted for expected exchange rate movements), indicating that controls continue to have noticeable effects. McKay (Chapter 15) notes the consequences of the payments surplus and increasing international financial integration for monetary policy. He observes that the Chinese authorities have been able to sterilise much of the domestic monetary consequences of foreign exchange reserves recently growing at a rate that has no precedent anywhere. Domestic policy will need support from exchange rate flexibility, but successful liberalisation will require careful management-and McKay suggests a process for effective change.

Golley and Tyers (Chapter 16) look over the current powerful tendencies to payments surplus, and examine long-term influences on the exchange rate. They argue that not all the long-term pressures will be supportive of appreciation.

Sun and Zhang (Chapter 17) point out links between the payments surplus and the appreciation of real estate asset values that were recently a powerful factor in Chinese development. The moderation of risks associated with real estate bubbles will require action across a wide range of instruments, including 
in exchange rate and fiscal policy. Rule (Chapter 13) tells a fascinating story of the growth and internationalisation of Chinese equity markets-to the point where market influence now goes from China to the world's major markets, as well as in the opposite direction.

Zhang (Chapter 19) describes how, from 1984, the Special Economic Zones played a major but transitional role in China's integration into the international economy. They were a place for experimentation with reform, and their success encouraged more general opening of the economy. Since about 2003, their proportionate role has declined.

Chen (Chapter 11) describes the broader history of direct foreign investment. The early years of reform involved slow progress in changing the regulatory, institutional and policy frameworks for direct foreign investment. Maturation of this process led to a high tide of investment from 1991 to 2001, with the proportionate role of new direct foreign investment peaking at the end of this period. Far-reaching liberalisation of direct foreign investment after WTO entry has nevertheless been important.

\section{Linking labour markets and the turning point in economic development}

Since the publication of The Turning Point in China's Economic Development a year ago (Garnaut and Song 2006), there has been much discussion and new research within China on the rising cost of labour in China and the implications of this for the national economy.

Wu (2007) recently reviewed some of the material. He records the results of research for the Development Research Center of the State Council, based on a survey of almost 3,000 villages in 17 provinces. The results of the survey indicate that 74 per cent of the villages no longer have any surplus labour available for employment in distant cities. The 'labour shortage' began in coastal areas but has now spread through the inland.

Wu also draws attention to the Green Paper on Population and Labour published by the Chinese Academy of Social Sciences (CASS) in June 2007. The paper argues that China is now approaching a 'Lewisian turning point' (compare this with the similar analytical framework applied in Garnaut 2006 and Garnaut and Huang 2006). It notes that labour will be 'short' throughout China by 2009-in rural as well as urban areas. It describes an acceleration in rates of increase in wages of rural migrant workers-from 2.8 per cent in 2004 to 6.5 per cent in 2005 and 11.5 per cent in 2006. Wu notes the conclusion drawn by CASS scholar Wu Yaowu that reforms of the hukou system to reduce barriers to internal labour migration are necessary in response to these large changes in the labour market. 
Garnaut and Huang (Chapter 2) present evidence of continuing strong wage growth, particularly in relatively poor inland and western provinces.

Cai, Du and Zhao (Chapter 8) focus on the increasing integration of the national labour market. They note that more than 100 million rural labourers have migrated to urban jobs (and 132 million people from rural areas are working in urban areas), alongside the re-employment of laid-off workers from stateowned enterprises. The restructuring of employment within a strongly growing economy has moved China towards a historical Lewisian turning point, at which surplus labour is no longer available to support rapid expansion of labourintensive industry. The looming labour shortage is generating pressure for more efficient integration of labour markets. Reform of the hukou system-with its systematic discrimination against migrants from rural areas-has begun, but so far with a strong bias in favour of migrants with relatively high education and skills. In any case, competition for labour in a post-Lewisian world will force deeper labour market integration. It will be accompanied by reduction in regional and other wage differentials, and an adjustment of labour relations legislation to reduce discrimination against labour-or else risk labour unrest. They note that a tendency for wages to rise more strongly in poorer than in richer regions can already be observed.

Meng and Bai (Chapter 9) offer a different perspective, based on detailed payroll data from seven labour-intensive factories operating in Guangdong Province between 2001 and 2004. The data have the advantage that they relate specifically to migrant workers. Meng and Bai found no evidence of a substantial tendency for incomes of migrant workers to rise in these factories in Guangdong in the early years of the twenty-first century.

\section{Linking goods and services in China and abroad}

A number of chapters document and analyse the effects of deepening domestic market integration, and analyse the relationship between domestic and international linkages.

Wang, Fan and Zhu (Chapter 3) apply a new index to measure the expanding role of markets in the Chinese economy. The role of markets in domestic and international economic relations has become large by any standards, with the process of change having been accelerated by WTO entry. Findlay, Pangestu and Lee (Chapter 6) apply innovative and productive approaches to analysis of liberalisation in the services sector. The parallel analysis of agricultural exchange by Huang, Liu, Martin and Rozelle (Chapter 7) demonstrates that the Chinese farm economy is more open to the international market than this sector in most industrialised countries, and that openness has been assisted by WTO entry. Li, Song and Zhao (Chapter 5 ) describe another dimension of the 
internationalisation of the Chinese economy in recent years: expansion of exports has been accompanied by huge growth in components imports from other East Asian companies, allowing China and its neighbours to specialise more and more finely in production and trade according to comparative advantage.

Two chapters look more broadly at the relationship between domestic and international market integration. Golley and Groenewold (Chapter 10) note that linkages across markets in China are less impressive than links to the international economy. The better-developed economies are more closely linked to overseas than internal markets. Chen, Gui, Lu and Chen (Chapter 18) conclude that deeper international integration tends to weaken domestic market linkages for a while, but to strengthen them at a later stage of development.

\section{The need for new markets for environmental amenity}

Chinese economic growth-like sustained economic growth in many countries-has been associated with pressure on the local environment. Chinese economic growth is now on such a prodigious scale that it is placing pressure on global environmental amenity through its contribution to current and prospective global warming.

A recent report from the Netherlands Environment Assessment Agency (2007) on global emissions of greenhouse gases recorded that China overtook the United States in 2006 as the country with the highest levels of greenhouse gas emissions-by a margin of 8 per cent. China contributed two-fifths of the 2.6 per cent growth in global emissions last year.

International market reform, embodying internalisation of global environmental externalities, is needed if the continuation of strong growth is to be reconciled with the conservation of aspects of the biosphere on which all human activity depends. These difficult but fundamentally important issues are discussed briefly in the concluding section of Garnaut and Huang (Chapter 2).

The Chinese dimension of the global warming issue has its origin in the extent and character of Chinese energy use in the process of rapid economic growth. Song and Sheng (Chapter 12) assess in detail the relationship between growth and energy consumption in China. They introduce recent official discussion of climate change in China to provide important insights into Chinese thinking and possible future contributions to management of this international issue.

\section{Integrating ideas about economics}

This volume concludes with reflections by Lin (Chapter 20) on the adequacy of ideas from modern neoclassical economics in understanding growth in China and other transitional economies in the reform period. 
One of the impressive and influential processes of linking Chinese to international markets in the reform era has involved the market for ideas about economics. The modern economics profession has grown prodigiously, so that the received economic wisdom of the West is understood and taught widely in the best universities and social science research institutions. Lin, and the China Center of Economic Research at Peking University, which he was instrumental in establishing, is the prime locus of this new knowledge.

One of the strengths of modern economics as professed in China is that it has been capable of critical rigour in application of ideas developed elsewhere to the Chinese situation. Lin analyses the sources of modern economics' failure to comprehend the failure of simple application of received doctrine in the former Soviet Union, and the success of departures from it in China. He draws attention to the importance of retaining a critical mass of 'viable' enterprises, which can maintain economic activity through disruptive structural change.

\section{Note}

1 Throughout the following chapters, the terms 'renminbi' and 'yuan' are used interchangeably.

\section{References}

Garnaut, R., 2006. 'The turning point in China's economic development', in R. Garnaut and L. Song (eds), The Turning Point in China's Economic Development, Asia Pacific Press, The Australian National University, Canberra:1-11.

Garnaut, R. and Huang, Y., 2006. 'Continued rapid growth and the turning point in China's development', in R. Garnaut and L. Song (eds), The Turning Point in China's Economic Development, Asia Pacific Press, The Australian National University, Canberra:12-34.

Garnaut, R. and Song, L. (eds), 2006. The Turning Point in China's Economic Development, Asia Pacific Press, The Australian National University, Canberra.

Netherlands Environmental AssessmentAgency (MNP), 2007. Chinanowno.1 in $\mathrm{CO}_{2}$ emissions; USA in second position, Press release, Netherlands Environmental Assessment Agency. Available from www.mnp.nl/en/service/pressreleases/ 2007/20070619Chinanowno1inCO2emissionsUSAinsecondposition.html

Stern, N., 2007. Stern Review Report on the Economics of Climate Change, Cambridge University Press, Cambridge. Available from www.hm-treasury. gov.uk/independent_reviews/stern_review_economics_climate_change/ sternreview_index.cfm

Wu, Z., 2007. 'China's cheap labour pool drying up', China Business, 17 June, Hong Kong. 